Piotr Strzyż

Uniwersytet Łódzki

\title{
„KUNSZT URINATORSKI JAKO RZEKI PRZEPŁYWAJA" CZYLI O POKONYWANIU PRZESZKÓD PODWODNYCH W XV-XVI WIEKU
}

\begin{abstract}
Streszczenie. W przeszłości podczas przekraczania przeszkód wodnych uciekano się do różnych sposobów: korzystano z brodów, budowano mosty czy tratwy, wreszcie sięgano po rozmaitej konstrukcji łodzie. Ówczesne traktaty wojskowe wspominają wszakże o jeszcze innych rozwiązaniach, które mogły być stosowane w szczególnych przypadkach. Były to specjalne urządzenia umożliwiające oddychanie oraz przemieszczanie się pod wodą, po dnie zbiornika. Korzystali z nich Urinatores, czyli ludzie, którym można było powierzyć zarówno niebezpieczne wojskowe akcje dywersyjne przeciwko flocie przeciwnika, jak i wykorzystać do odzyskiwania utraconego w wodzie sprzętu wojennego czy udrożnienia kanałów lub rzek.

Średniowieczna i renesansowa ikonografia dowodzi, iż przyrządy, jakimi się posługiwali, mogły mieć dwojaką postać. Po pierwsze były to skórzane, nadmuchiwane pasy, zapinane na brzuchu, do których zamocowana była elastyczna rura. Dodatkowe wyposażenie stanowiły odpowiednio obciążone ołowiem buty oraz broń odporna i zaczepna. Drugi wariant opracowanych dla nurków urządzeń to specjalny, skórzany czepiec na głowę, zaopatrzony w chronione szkłem otwory wzrokowe oraz doszytą długą rurę oddechową z pływakiem. Tak przygotowany nurek mógł przebywać pod wodą nawet kilka godzin. Dla terenu Królestwa Polskiego informacje na ten temat zawierają Księgi Hetmańskie Stanisława Sarnickiego z 2 poł. XVI w. Specjaliści tacy byli z pewnością bardzo przydatni, ale zajęcie, którego się podejmowali, było niezwykle niebezpieczne, szczególnie jeśli uwzględni się prymitywizm środków, którymi dysponowali.
\end{abstract}

Słowa kluczowe: Królestwo Polskie, urinator, przeprawy, wojna, średniowiecze, XVI w.

Przeszkody wodne w przeszłości stanowiły poważne utrudnienie komunikacyjne zarówno w odniesieniu dla wojsk, jak i użytkowników cywilnych. W starożytności, średniowieczu i czasach nowożytnych podczas przekraczania akwenów uciekano się do różnych sposobów, z których najłatwiejszym 
i angażującym najmniej wysiłków było wyszukanie odpowiedniego brodu. Umożliwiał on zwykle szybkie i bezproblemowe przedostanie się na drugi brzeg rzeki, choć była to przeprawa bardzo podatna na zmienne warunki pogodowe. Z czasem do przeprawienia zaczęto wykorzystywać konstrukcje inżynierskie w postaci mostów zarówno tych mobilnych - stawianych na łodziach czy beczkach, jak i stałych. W sprzyjających okolicznościach można było również wykorzystać tratwy bądź łodzie ${ }^{1}$. Ówczesne traktaty wojskowe wspominają jeszcze jednak o rozwiązaniach, które mogły być stosowane w szczególnych przypadkach. Były to specjalne urządzenia umożliwiające oddychanie oraz poruszanie się pod wodą, po dnie zbiornika. Korzystali z nich urinatores, zapewne ludzie niepospolitej odwagi, którym nie była straszna klaustrofobiczna ciemność rzek, jezior czy morskich zatok. Jednocześnie śmiałkowie ci nie zwracali nadmiernej uwagi na mankamenty urządzeń, którymi mieli się posługiwać w swych misjach. Osobom takim można było powierzyć zarówno niebezpieczne zadania wojskowe (np. atakowanie okrętów przeciwnika), jak i wykorzystać ich do odzyskiwania utraconego w wodzie sprzętu wojennego, udrażniania zatarasowanych kanałów rzecznych lub portowych czy odzyskiwania zatopionych kosztowności.

Przekazy pisane, jak i ikonografia dowodzą, że wspomniani urinatores mogli korzystać z różnych technik, aby pokonać przeszkodę wodną. Najprostszą z nich było wykorzystanie do przebycia rzeki własnych umiejętności pływackich. Osoby zajmujące się tym niejako „zawodowo”, miały odpowiednio wyćwiczone płuca, umożliwiające dłuższe przebywanie pod wodą. Często jednak stosowano „wspomaganie” w postaci dmuchanego, skórzanego worka. Zapewniał on pływakowi dodatkową wyporność, przydatną szczególnie w trudnych warunkach pogodowych (ryc. 1). Nie miał on wówczas możliwości nurkowania pod wodę, lecz mógł w miarę bezpiecznie utrzymać się na jej powierzchni. Sposoby tego rodzaju znane są już ze starożytności ${ }^{2}$. Z powodzeniem w średniowieczu z takich

1 Szerzej np. A. Rutkowska-P£achcińska, Urzadzenia transportowe i komunikacyjne, [w:] Historia kultury materialnej, t. 2 (od XIII do XV wieku), red. Z. Hensel, Wrocław 1978, s. 213-220; P. STrzyż, Water Obstacles and the Means to Cross Them in Early Medieval Poland, "Fasciculi Archaeologiae Historicae” 2011, fasc. 24, s. 73-78; T. Grabarczy , „Sucha stopa” czy „skaczac przez fale”. Przekraczanie rzek przez wojska polskie od XI do początku XVI wieku, „Acta Universitatis Lodziensis", Folia Historica 99, 2017, s. 83-106.

2 Pierwowzór tego rodzaju urządzeń można odnaleźć już w dziele De re Militari libri $V$, którego autorem był Rzymianin Publius Flavius Vegetius Renatus (Vegetius), żyjący na przełomie IV i V w. n.e. 
skórzanych worków korzystali np. Mongołowie, co rzeczowo opisał Giovanni di Piano Carpini, włoski franciszkanin, emisariusz papieża Innocentego IV do chana mongolskiego w latach $1245-1247^{3}$.

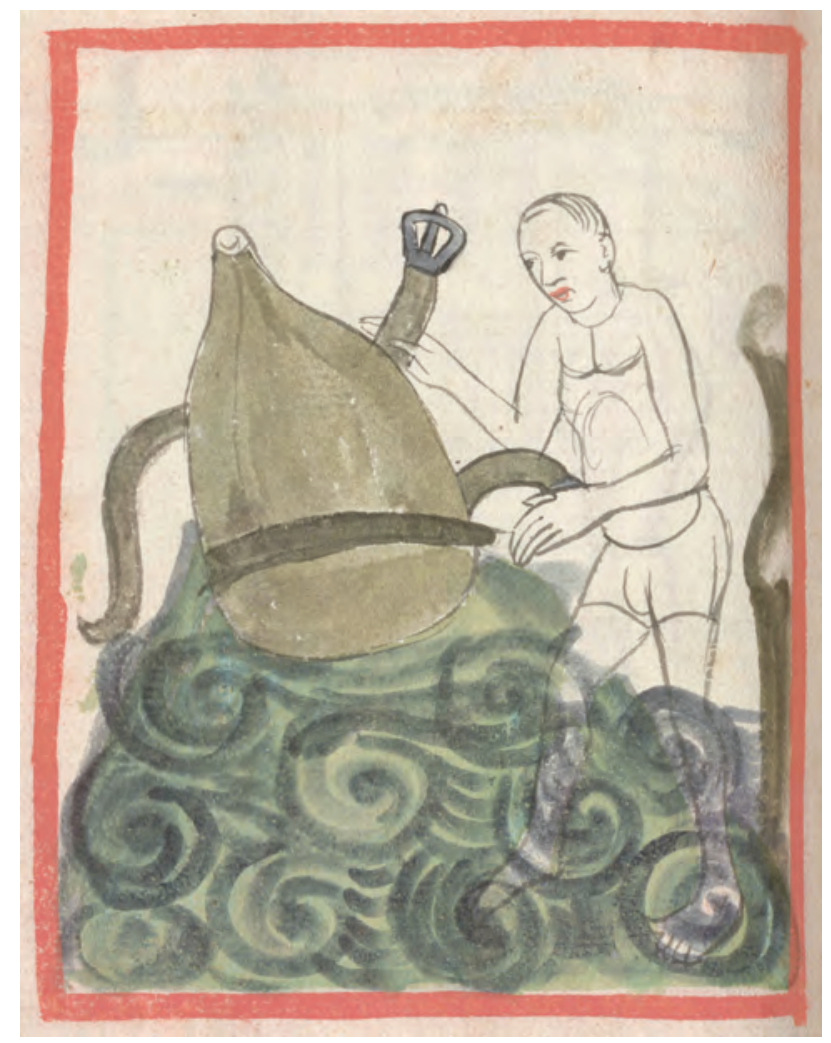

Ryc. 1. Przygotowanie skórzanego pasa wspomagającego pływanie (Źródło: Büchsenmeisterbuch. Österreichische Nationalbibliothek, Wien, Cod. 3069, fol. 54v, ok. 1411, http://digital.onb.ac.at/RepViewer/viewer.faces?doc=DTL_2316748\& order=1\&view=SINGLE, dostęp: 31 X 2019)

Jego prace były kopiowane przez całe średniowiecze (znanych jest około 150 rękopisów), ale drukiem zaczęto je wydawać począwszy od $1473 \mathrm{r}$. i były drukowane jeszcze w XVI w., $c f$. T. NowaK, $Z d z i e-$ jów techniki wojskowej w dawnej Polsce, Warszawa 1965, s. 29-30. Jeszcze starsza jest asyryjska płaskorzeźba z IX w. p.n.e ze zbiorów British Museum w Londynie, przedstawiająca nurków ze skórzanymi workami do oddychania, $c f$. C. Rossi, F. Russo, F. Russo, Ancient Engineers' Inventions. Precursors of the Present, Heidelberg 2017, s. 143, ryc. 9.1.

3 S. KaŁużyński, Dawni Mongotowie, Warszawa 1975, s. 85, 280; W. Śwį̨TosŁaWski, Breaching of Water Obstacles in the Military Activites of Late Medieval Mongols, „Fasciculi Archaeologiae Historicae" 2011, fasc. 24, s. 80. 
Jednym z takich dzieł, w którym odnajdujemy informacje na temat pasów pływackich, jest ilustrowany traktat Konrada Kyesera Bellifortis z około 1405 r. Powszechnie przyjmuje się, że ukończony on został na zamku Žebrák pod koniec życia jego twórcy. Wśród 140 foliałów rękopisu znalazły się zarówno przedstawienia uzbrojenia, urządzeń techniczno-wojskowych, machin miotających czy artylerii ogniowej, jak i „wynalazków” w rodzaju ogrzewanych łaźni oraz machin latających. Ilustracjom tym towarzyszą łacińskie opisy, tłumaczące zasady działania projektowanych urządzeń. Warto w tym miejscu podkreślić, iż Kyeser, urodzony w 1366 r. w Eichstätt, w latach osiemdziesiątych i dziewięćdziesiątych XIV w. odbył wiele podróży po Europie Zachodniej, służąc m.in. na dworach niemieckim czy włoskim. Tu też miał możność zapoznać się bliżej z ówczesną techniką wojskową. Około roku 1394 służył u Jana, księcia zgorzeleckiego, brata czeskiego króla Wacława IV. W 1396 r. wraz z armią Jana Luksemburskiego wziął udział w wyprawie przeciwko Turkom, która zakończyła się porażką pod Nikopolis. Następnie od 1397 r. przebywał w Bawarii, Austrii czy na Śląsku, po 1401 r. zaś można go spotkać znów na dworze króla Wacława IV, gdy osiadł w Kutnej Horze. Ostatnia wzmianka pochodzi z 23 czerwca 1405 r., kiedy to właśnie na zamku Žebrák napisał przedmowę do swego traktatu ${ }^{4}$. Kyeser był zatem osobą, która na wojskowej stużbie na wielu dworach i wielu teatrach wojennych spędziła znaczną część życia. Przełożyło się to na zdobyte doświadczenie i praktyczną wiedzę z zakresu techniki wojskowej.

Na kartach kodeksu, wśród wielu nowatorskich rozwiązań, odnajdujemy też ilustracje z urządzeniami do poruszania się, pracy, a nawet - do walki pod wodą 5 . W pierwszej kolejności jest to przyrząd, który zwiększa wyporność, co ułatwia pływanie:

To jest instrument, z którym możesz pływać,

Zawiąż słuchawkę na brzuchu, z rurą oddechową podniesioną do góry,

Wschodni wiatr [w znaczeniu powietrze wydychane - P.S.] pozwoli go nadmuchać,

Przytrzymaj go mocno, kiedy go złapiesz, dopóki nie pozwoli ci odpłynąć ${ }^{6}$.

${ }^{4}$ J. Durdík, K vojensko-technickým problémuim na počátku 15. století (Bellifortis Konráda Kyesera), „Historie a vojenstvi” 1953, z. 3, s. 30-31; B. Drake Boehm, J. Fajt, Wenceslas IV, [w:] B. Drake Boenm, J. Fajt, The Crown of Bohemia 1347-1437, New York 2005, s. 99-100; D.H. Breiding, The Bellifortis of Konrad Kyeser of Eichstätt, [w:] B. Drake Boenm, J. Fajt, Prague..., s. 233-235, nr kat. 89.

Cf. J. Durdík, op. cit., s. 38.

${ }^{6}$ Konrad Kyeser, Bellifortis, Umschrift und Übersetzung Götz Quarg, Düsseldorf 1967, cz. 2, s. 37: „Et hoc instrumentum cum quo natare valebis | Ante ventrem liga capud dependent cauda | 
Informacje te zostały powtórzone też w dalszej części rękopisu i są w znaczniej mierze zbieżne z pierwszym zapisem:

Delikatnie jest to uszyte jako rurowy [pusty - P.S.] pas,

część środkowa zapina się na uszka [sprzączki - P.S.], część tylna również,

Długa rura wisi swobodnie i służy do nadmuchiwania,

W ten sposób twoje ciało bezpiecznie przekroczy wszystkie wody?

Jednak na jednej z kolejnych kart został zawarty dość szczegółowy opis konstrukcji nowocześniejszego urządzenia, pozwalającego człowiekowi na przebywanie pod wodą. Stało się to możliwe dzięki zapewnieniu mu swobodnego oddychania:

W podobny sposób to urządzenie ma na celu to samo,

Z wyjątkiem tego, że głowa także składa się ze skóry,

Ale przez miedzianą rurę do ust prowadzi pęcherz.

Stąd tykasz powietrze, wydychasz je albo zatrzymujesz.

Kiedy woda płynie albo ci ciąży

Przez ruch, niech ołowiany ciężar cię obciąży

Albo przywiąż linę zatrzymującą do jakiegoś drzewa,

Za pomocą której przez wymagany czas utrzymasz się na miejscu.

Tak będziesz kroczył pewnie. Co zostało powiedziane, tego się trzymaj.

Jest to urządzenie wodne, następująco wykonane

Hełm zbrojny niech będzie przeszyty gąbką,

Następnie pójdzie szata krojona ze skóry,

Pośrodku której się przepasz, dalej gąbki podwójne

Oczy maski niech będą wykonane ze szkła

$\mathrm{Z}$ ich pomocą zobaczysz i rozejrzysz się wokół,

Też wszystko, czego chcesz, pochwycisz, uniesiesz i podejmiesz ${ }^{8}$.

Ventus orientis posteriora | Quem captum teneas donec exire licebit". Za pomoc w thumaczeniu tekstów łacińskich dziękuję prof. dr. hab. Grzegorzowi Żabińskiemu z Uniwersytetu Humanistyczno-Przyrodniczego im. Jana Długosza w Częstochowie.

${ }^{7}$ K. Kyeser, op. cit., cz. 2, s. 43: „Placidum est istud rotulari cingulo sutum | Medium per aura ligatur et posteriora. Longum namque girat sufflando ventum ministrat. Sic albeas cunctas transis meas coropre tuo".

${ }^{8}$ K. KYESER, op.cit., cz. 2, s. 40: „Similiter istud instrumentum tendit ad idem | Excepto quod capud sit etiam sic coreatum | Cannaque cuprea per os vesciam subintret | Inde capis aerem, remittis tenes eundem | Lympha si sit mobilis vel nocitatur tibi | Ex agilitate, plumbeum pondus te geavabit | Seu ligamentum ligabis ad arborem quendam | Per quod te immittes manens infra tempus adoptatum | Nam sic salvus meas que sunt narrata teneto. 

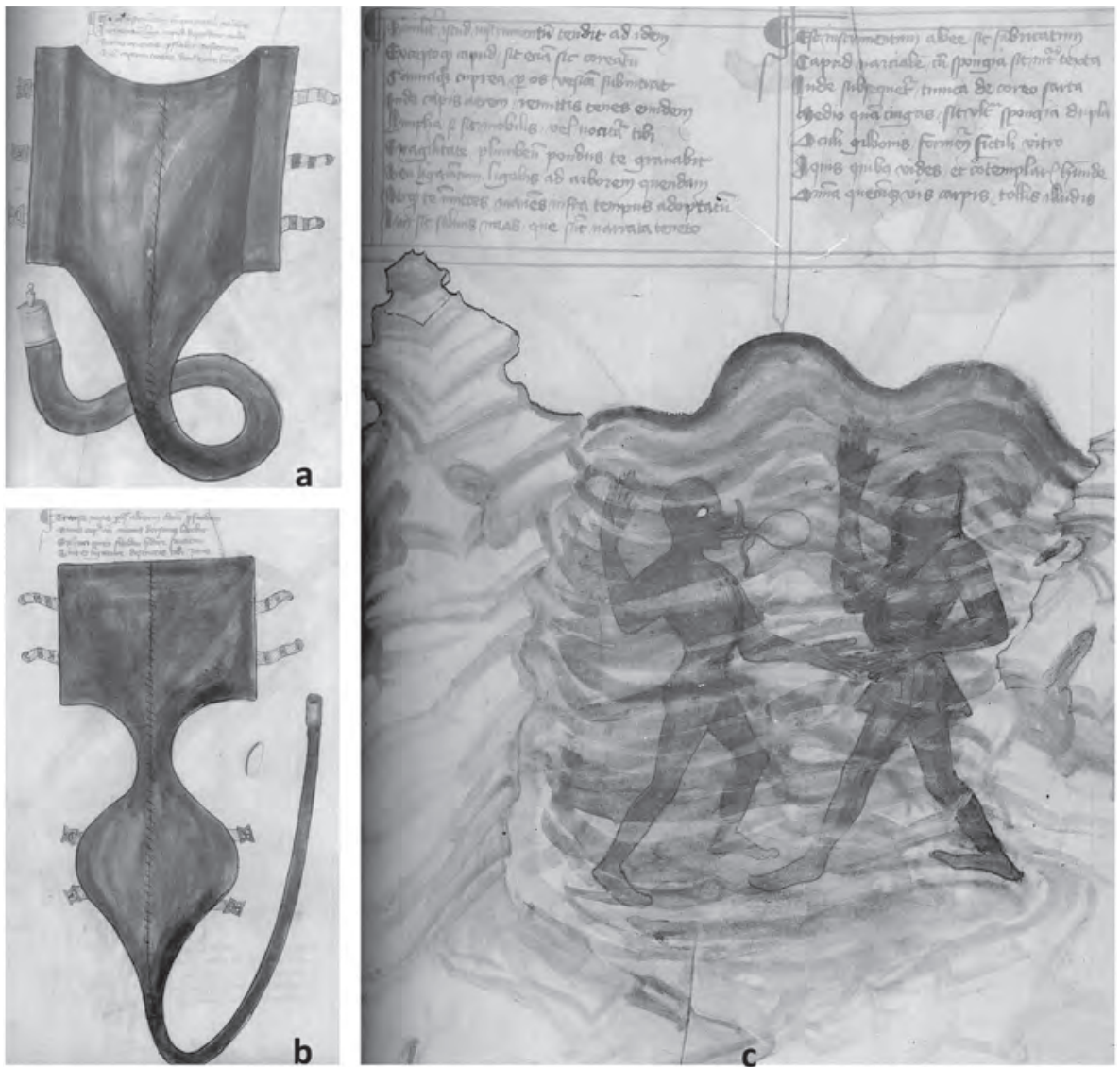

Ryc. 2. a - pas do pływania, fol. 55; b - pas do pływania, fol. 63v; c - podwodna walka dwóch nurków, fol. 62 (Źródło: K. KYESER, Bellifortis, Düsseldorf 1967, cz. 1)

Projekty urząadzeń do podwodnego poruszania się dość szybko upowszechniły się w średniowiecznej ikonografii. Dobrym przykładem takiego źródła jest kodeks Büchsenmeisterbuch, powstały około 1411 r., a obecnie przechowywany w Bibliotece Narodowej w Wiedniu. W przeważającej mierze poświęcono go sprawom związanym z produkcją i obsługą broni ogniowej, ale kilka foliałów dotyczy też pasa wspomagającego utrzymanie się na wodzie. Przede wszystkim jest to instrukcja dokumentująca budowę, ale i sposób zakładania oraz posługiwania

Est instrumentum albee sic fabricatum | Capud marciale cum sponga sit intratexta | Inde subsequetur tunica de coreo Sarta $\mid$ Medio quam cingas sit ultra spongia dupla | Oculi gilbonis formentur fictili vitro | Aquis quibus vides et contemplaris hucunde | Omnia quecumque vis carpis tollis illudis". 


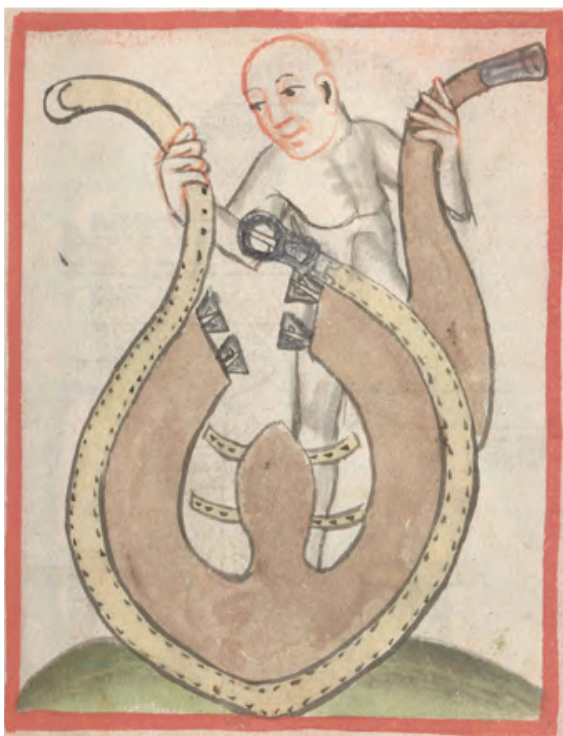

a

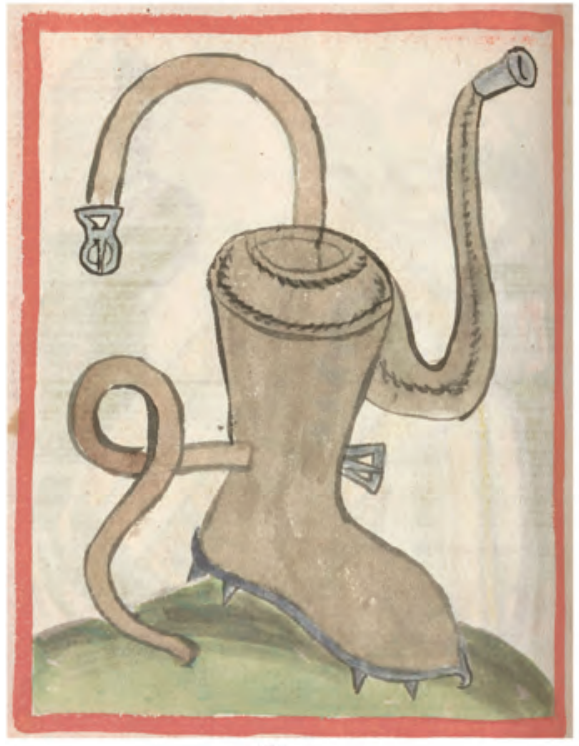

C

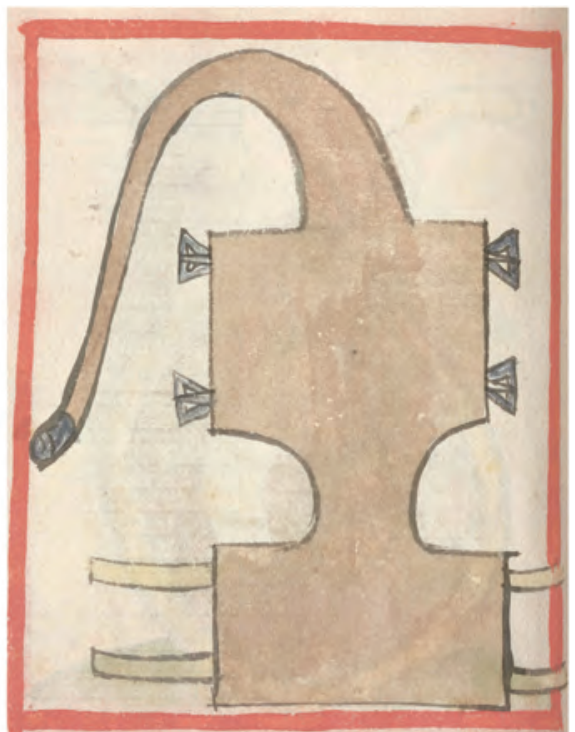

b

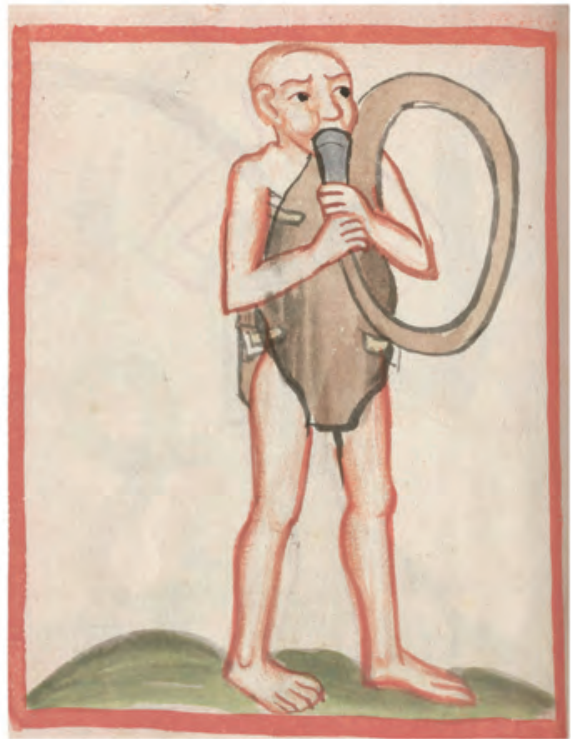

d

Ryc. 3. a - zakładanie pasa do pływania, fol. 60; b - pas do pływania, fol. 60v; c - buty do chodzenia pod wodą, fol. 61; d - zasada działania pasa do pływania, fol. 62v (Źródło: Büchsenmeisterbuch, Österreichische Nationalbibliothek, Wien, Cod. 3069, ok. 1411, http://digital.onb.ac.at/RepViewer/viewer.faces?doc=DTL_2316748\&order= 1\&view=SINGLE, dostęp: 31 X 2019) 


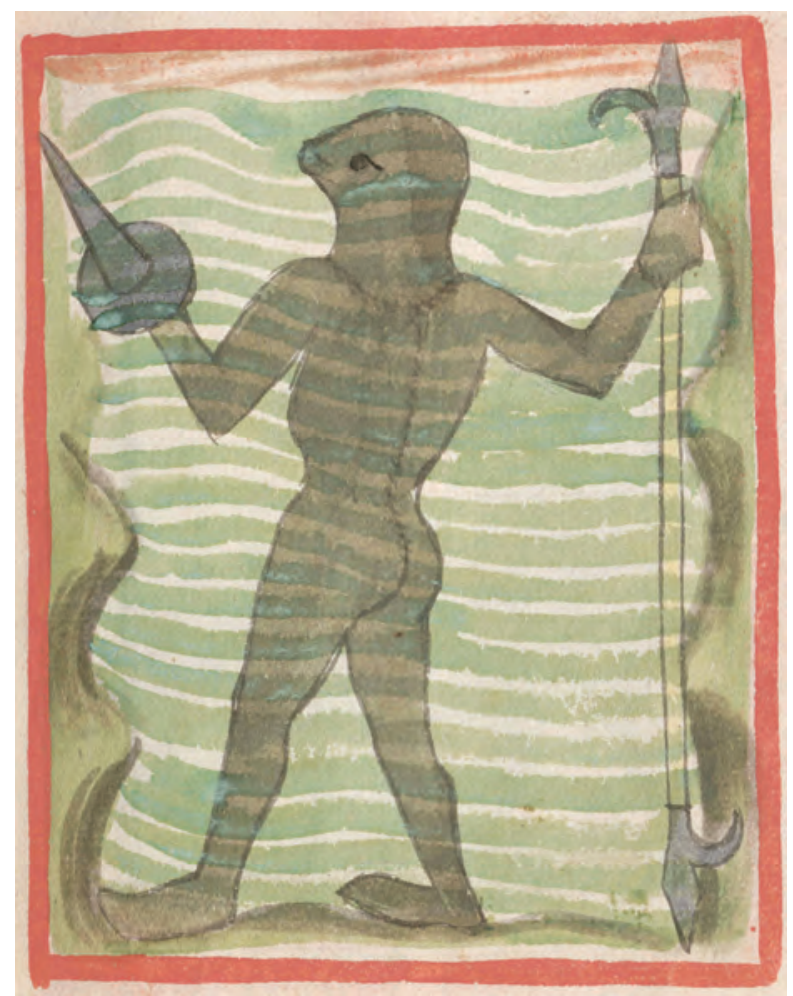

Ryc. 4. Nurek w pełnym wyposażeniu podwodnym (Źródło: Büchsenmeisterbuch, Österreichische Nationalbibliothek, Wien, Cod. 3069, fol. 66, ok. 1411, http://digital.onb.ac.at/ RepViewer/viewer.faces?doc=DTL_2316748\&order=1\&view=SINGLE, dostęp: 31 X 2019)

się skórzanym pasem na powietrze. Został on narysowany bardzo dokładnie, zaznaczono szwy, sprzączki oraz rurę oddechową. Przedstawiono także odpowiednie do tego celu obuwie, być może obciążone ołowiem - jak zalecał Konrad Kyeser, ale i z kolcami do stąpania po śliskim dnie (ryc. 3).

Osobno został przedstawiony też „nurek”, który pod wodą przebywa w specjalnym skafandrze. Podobnie jak w traktacie Bellifortis, jest on wyposażony w broń drzewcową - na każdym z końców zaopatrzoną w grot z hakiem (lub może podwójnie okuty bosak), a w drugiej ręce trzyma oręż na podobieństwo puginału z szeroką tarczką ochronną lub może specjalnej tarczy - „puklerza”.

Podobny przykład znajdujemy również w powstałym około 1420-1440 r. traktacie Kriegstechnik. Na jego kartach można zaobserwować zarówno uri- 


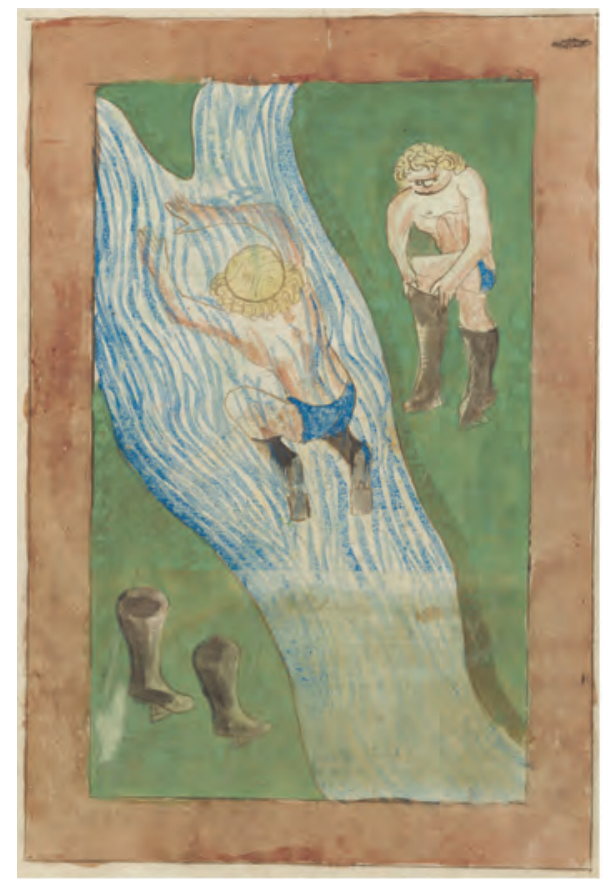

a

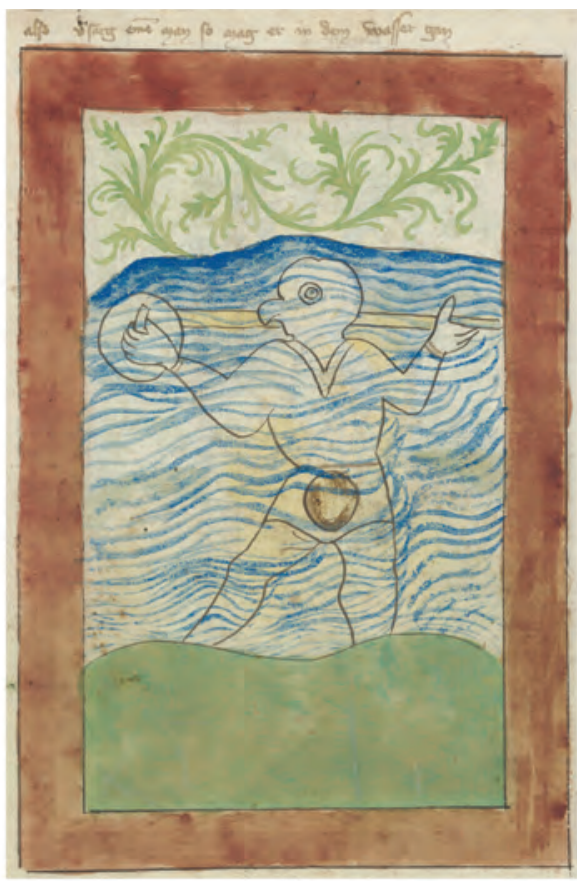

b

Ryc. 5. a - urinator nurkujący w rzece, fol. 155; b - nurek w pełnym wyposażeniu bojowym, fol. 76v.

(Źródło: Kriegstechnik, ok. 1420-1440, Zentralbibliothek Zürich, Ms. Rh. Hist. 33b,

http://www.e-codices.unifr.ch/de/searchresult/list/one/zbz/Ms-Rh-hist0033b, dostęp: 10 X 2019)

natorów pływających w rzece bez żadnych dodatkowych urządzeń (ryc. 5a), jak i zbrojnego chodzącego pod wodą, po dnie zbiornika. Także ten śmiałek jest uzbrojony w bliżej nieokreśloną broń drzewcową (grot jest niewidoczny), a w drugiej ręce trzyma niewielką kolistą tarczę z imaczem (ryc. 5b).

Człowiek wyposażony w pas do pływania mógł, co prawda, swobodnie pływać po wodzie, nie mógł jednak przebywać przez dłuższy czas pod jej powierzchnią. Rozwiązanie tego problemu stanowił kaptur zaopatrzony w wizjery - szkła, który w górnej części przechodził w rurę z doczepionym pływakiem. Pozwalał on rurze oddechowej unosić się nad powierzchnią wody, zapewniając nurkowi stałą możliwość oddychania powietrzem atmosferycznym (ryc. 6a, b). Opisy tego rodzaju urządzenia znajdujemy już w dziele Konrada Kyesera?

\footnotetext{
9 Cf. K. Kyeser, op. cit., cz. 1, fol. 62; cz. 2, s. 40.
} 


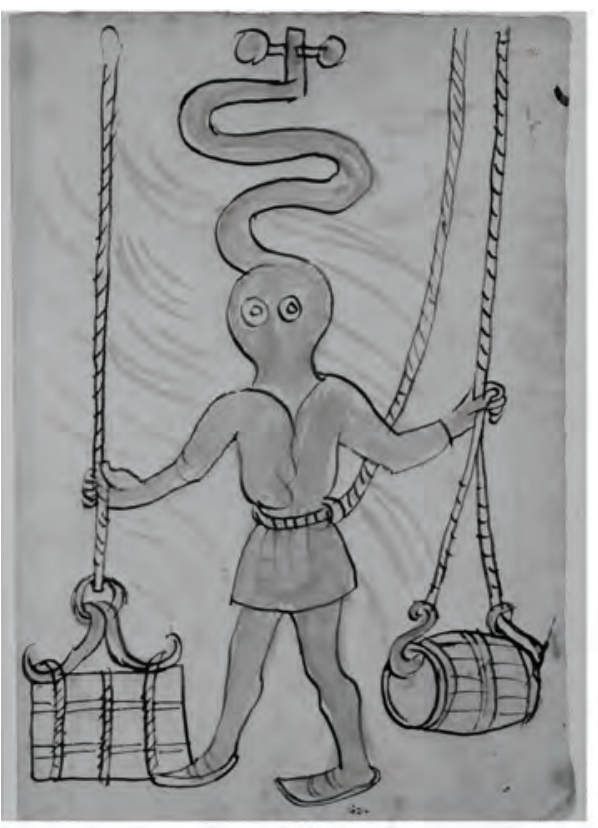

a

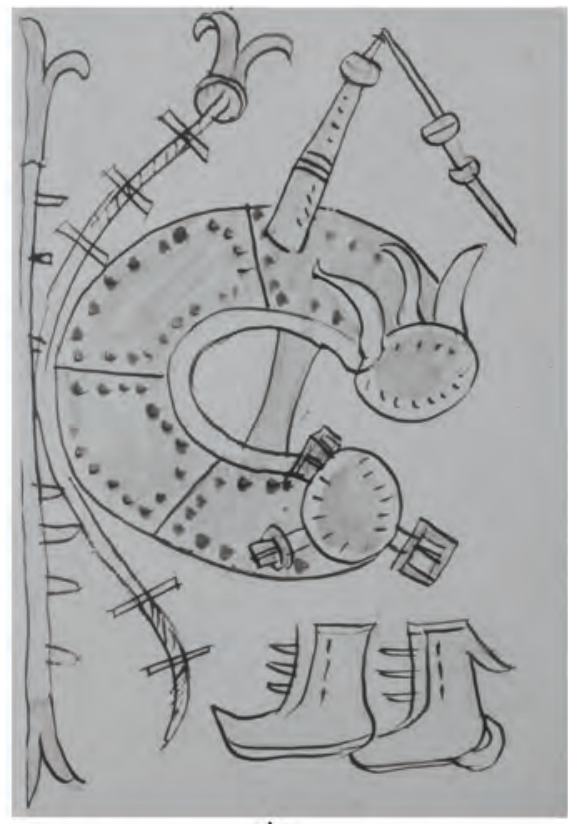

b

Ryc. 6. a - nurek z kapturem oddechowym wydobywający zatopione towary na powierzchnię, fol. 14; b - wyposażenie nurka: worek, buty, bosak, fol. 13 (Źródło: Anonym, Bayerische Staatsbibliothek, München, Clm 197, ok. 1440)

Osoba wyposażona w taki kaptur mogła poruszać się po dnie zbiornika bez ograniczeń warunkowanych pojemnością skórzanego worka. Wydaje się jednak, iż pewne niebezpieczeństwo stwarzały warunki pogodowe, przy wysokich bowiem falach do wnętrza rury mogła dostawać się woda, grożąc zatopieniem nurka. Należało też uważać na przebieg i głębokość dna zbiornika wodnego, wszelkie uskoki terenu mogły bowiem spowodować, wobec zbyt krótkiej rury, utonięcie nurka.

Powyższe rozwiązania, znane z traktatów zachodnioeuropejskich, znalazły odbicie także w twórczości polskich teoretyków wojskowych w XVI stuleciu. Takim dziełem są Księgi Hetmańskie... Stanisława Sarnickiego, w których na polskim gruncie napotykamy pierwsze opisy specjalistów zdolnych do poruszania się pod wodą. Autor zawarł w nim zapewne częściowo swe doświadczenia wyniesione z podróży do Włoch (Padwa, Trydent, Wenecja), które uzupełnił informacjami pozyskanymi z lektury takich taktyków włoskich, jak choćby 

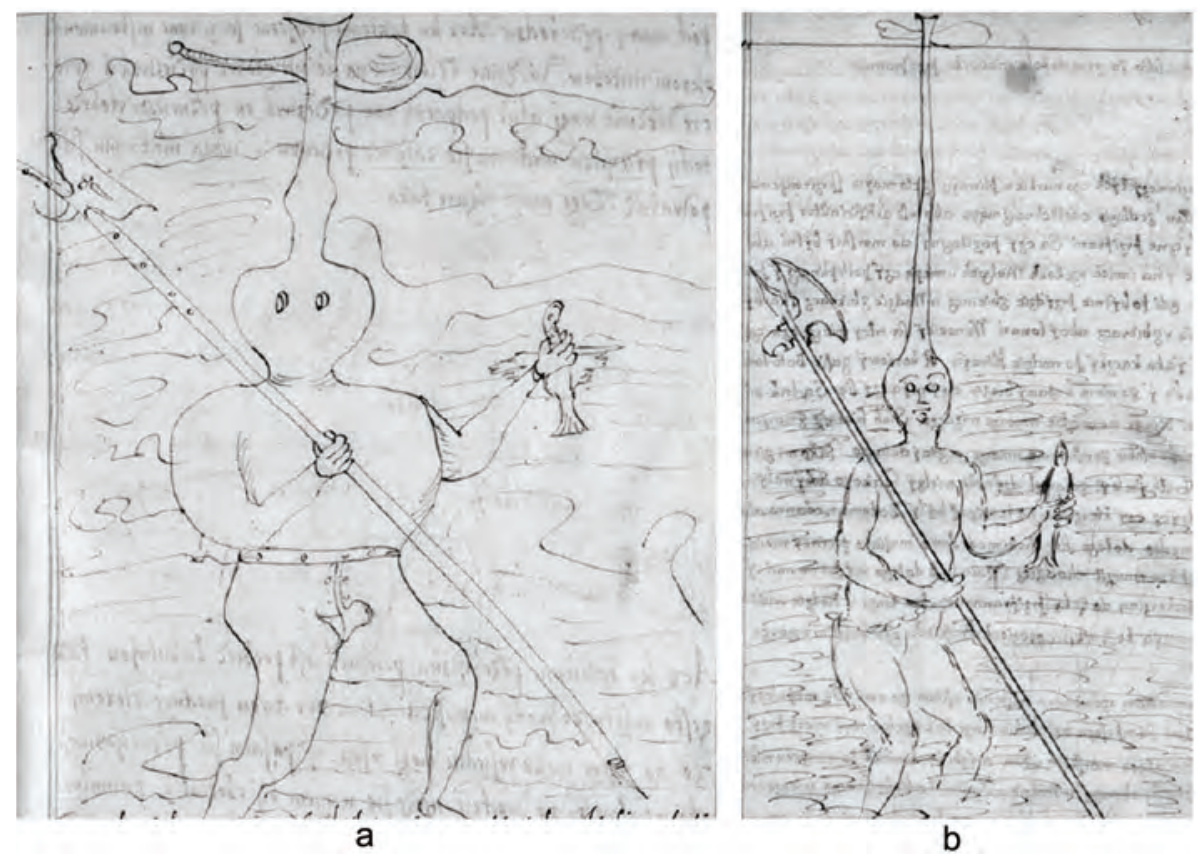

Ryc. 7. a, b - nurek w kombinezonie zaopatrzonym w rurę - „kominek”, umożliwiającą korzystanie z powietrza atmosferycznego pod wodą (Źródło: SARNICKI, ryc. 28)

Roberto Valturius ${ }^{10}$. Pierwsza wzmianka dotyczy zasadniczo nurków wykorzystujących pojemność własnych płuc: „Urinatorem zowią łacinnicy tych co nurkiem pływają, że to mają z przyrodzenia, że są przestronnych płuców, że długo odetchnąć albo też artificialiter przyprawują, bo są do tego rozliczne przyprawy. Są ci pożyteczni do morskiej bitwy albo i na Dunaju, na Nieprze [Dnieprze] i na innych rzekach wielgich. Umieją ci podpłynąć i powiercić okręty. Umieją, gdy po bitwie przyjdzie w wodzie zbierać skarby, działa które zatopywują uzbierać albo i towary"11.

${ }^{10}$ Dzieło Valturiusa, De re militari libri XII, Paris 1532, stanowiło istotną inspirację dla SARNICKIEgo, który właściwie przerysował wiele ilustracji z pierwowzoru, $c f$. J. Sikorski, Polskie piśmiennictwo wojskowe od XV do XIX wieku, Warszawa 1991, s. 111.

${ }^{11}$ Staniseaw SARNicki, Ksiegi Hetmańskie z dziejów rycerskich wszystkich wieków zebrane i praktyka abo experientia hetmanów Najjaśniejszego Zygmunta Starego Króla Polskiego, a także Cesarza Karla Vi Solimana Tureckiego dwu panów walecznych za naszego wieku objaśnione ku ćwiczeniu mtodych ludzi nacyjej naszej Polskiej pod tytutem, oprac. M. Ferenc, Kraków 2015, s. 178 [dalej: SARNiCKI]. 
Oprócz wyćwiczonych płuc nurkowie mogli dla dłuższego przebywania pod wodą korzystać ze wspomnianych specjalnych przyrządów (ryc. 7a, b), znanych już z przytoczonych powyżej, starszych dzieł: „Mają i inne miechy z kominkiem rzemiennym misternie uszytem, że wody w się nie puści, jeno oddech człowieczy, który się spuszcza w głębokie morze, tak iże musi tam przy sobie mieć buławę i halabardę broniąc się morskim rybom. A iżby ten kominek po wierzchu wszędzie następował gdzie jeno się obróci w wodzie urinator, tedy do samego wierzchołku kominka przywiążą pęcherz nadęty mocny, który onemu kominkowi nie da się zanurzyć, ani nakrzywić, alie wszędy następuje wierzchem gdzie jeno człowiek on postępuje spotkiem"12.

Autor podaje też informacje, iż był niegdyś naocznym świadkiem takich wydarzeń „Przed niedawnymi czasy był też tu w Rusi jeden Italian z takiem miechem i ubierał się weń i śmiała mu się śliachta jako maskarnikowi. Ten się podejmował rzek przeczyszcziać dlia wolnego przechodu szkut do Gdańska. I miał w Wieprz głęboko wbrodzić i tam kłody drzewa wywarzać na wierzch"13. Jego praca okazała się, jak widać, bardzo pożyteczna. Praktyczne stosowanie tego rodzaju rozwiązań potwierdza też dzieło Hiszpana Diego de Ufano, które w XVII w. było też popularne w Polsce jako podręcznik artyleryjski14 ${ }^{14}$ (ryc. 8).

Wreszcie w Ksiegach hetmańskich... Stanisław Sarnicki opisał też dość prymitywny przyrząd (ryc. 9) do chodzenia pod wodą „Alie w arsenale weneckim takich instrumentów siła, kędy też wojsko do wojska przez rzekę lieży, tedy szpiegowie mogą w takich miechoch do nich i do miast pod mury podchodzić. Acz ku takiemu prześciu są i inne instrumenta okrom miechów. Weźmie człowiek na się na głowę przycirek [naczynie drewniane - mała beczka], a w ręce weźmie wagi, alie pod pachy ma przycirek on przywiązać dobrze, tedy przejdzie, nie da mu się zaliać przecirek, waga nie da mu się powalić"15.

Tego rodzaju urządzenia były zapewne najbardziej niebezpieczne, gdyż przy jakimkolwiek wypadku nurek zostawał sam w głębinach, bez szans na pomoc z zewnątrz. Także zaproponowany w Ksiegach hetmańskich... przycirek alias dzwon jest całkowicie niepraktyczny z uwagi na brak jakichkolwiek otworów

12 Ibidem, s. 179.

13 Ibidem.

14 Dzieło to zostało wydane przez Jana Dekana pod tytułem Archelia albo Artilleria, to iest Fundamentalna y Doskonata Informacya o Strzelbie y o rzeczach do niey należacych, Leszno 1643, cz. 1-3; cf. np. T. Nowak, Polska sztuka wojenna w czasach Odrodzenia, Warszawa 1955, s. 96-99, 113, 114-116, 136; IDEM, $Z$ dziejów..., s. 220-221; J. SiKORSKI, op. cit., 143-144.

15 SARNICKI, s. 179-180. 


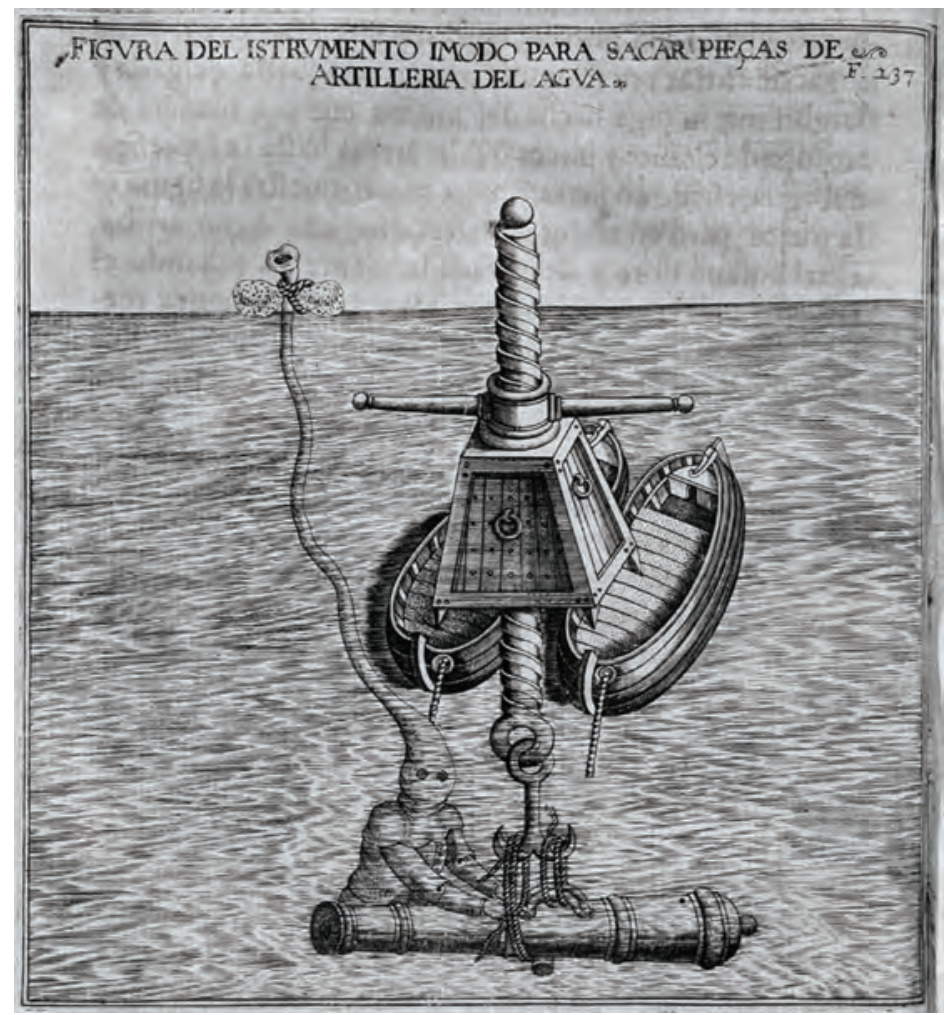

Ryc. 8. Wydobywanie zatopionego działa z morza (Źródło: Tratado de la artilleria y uso della platicado por el capitan Diego Ufano en las guerras de Flandes, Brusselas 1613, Biblioteca de la Universidad Complutense de Madrid, s. 237, http://bibliotecavirtualdefensa. es/BVMDefensa/i18n/consulta/registro.cmd?id=1192, dostęp: 31 X 2019)

wzrokowych. Niemniej tego rodzaju urządzenia, w postaci dzwonów do nurkowania, pojawiają się w dziełach dotyczących „zdobywania” morskich głębin już w 1. poł. XVI w. i były popularne w stuleciach następnych, jednak wówczas były one już wykonane z metalu i miały odpowiednie szklane wizjery ${ }^{16}$.

Zaprezentowane powyżej urządzenia do poruszania się po i pod wodą stanowią interesujący przyczynek do poznania najstarszych dziejów podejmowanych

${ }^{16} \mathrm{~Np}$. Jaсов Leupold, Theatrum Pontificale oder Schau-Platz der Brücken und Brücken-Baues, Leipzig 1726, s. 5, tab. I:7, Max Planck Institute for the History of Science, http://echo.mpiwg-berlin.mpg.de/ECHOdocuView ?url=/permanent/library/AUFTS19S/index.meta [dostęp: $31 \mathrm{X}$ 2019]; J. Bevan, Diving bells through the centuries, „South Pacific Underwater Medicine Society Journal" 1999, vol. 29, z. 1, s. 42-50. 


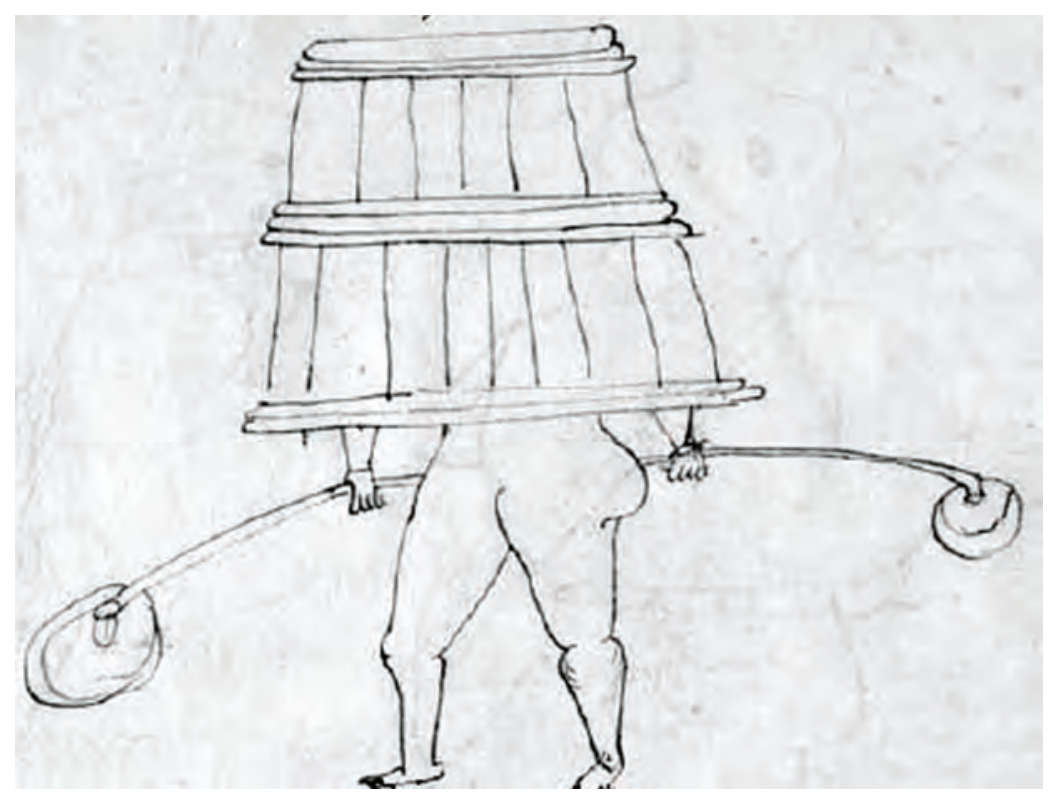

Ryc 9. Nurek korzystający z „przycirka”, prototypu późniejszego dzwonu (Źródło: SARNICKI, ryc. 29)

przez człowieka prób „podboju” podwodnych głębin. Także z terenu Polski dysponujemy informacjami o stosowaniu tego rodzaju urządzeń, co stanowi ciekawy przyczynek do adaptacji rozwiązań znanych z obszarów zachodnioeuropejskich. Jednak ówczesny poziom techniki powodował, iż próby te nie mogły wykroczyć poza, zapewne incydentalnie, podejmowane akcje z udziałem nielicznych śmiałków, którym nie straszne były głębiny zamieszkiwane rzekomo przez groźne „potwory”. Z uwagi na jeszcze dość prymitywną formę zaproponowanych urządzeń, tylko nieliczni, skuszeni zapewne wynagrodzeniem, decydowali się podejmować tak śmiałe zadania, ryzykując własne życie. Stan ten utrzymał się właściwie aż po wiek XIX, gdyż dopiero wówczas na szerszą skalę zaczęto stosować bardziej zaawansowane kombinezony, zaopatrzone w wodoszczelne, metalowe hełmy, zapewniające minimum bezpieczeństwa. 


\section{BIBLIOGRAFIA}

\section{Źródła}

Anonym, około 1440, Bayerische Staatsbibliothek, München, Clm 197.

Büchsenmeisterbuch, około 1411, Österreichische Nationalbibliothek, Wien, Cod. 3069, http://digital.onb.ac.at/RepViewer/viewer.faces?doc=DTL_2316748\&order= 1\&view=SINGLE [dostęp: 31 X 2019].

Konrad Kyeser, Bellifortis, Umschrift und Übersetzung Götz Quarg, Düsseldorf 1967, cz. 1-2. Kriegstechnik, Zentralbibliothek Zürich, Ms. Rh. Hist. 33b, http://www.e-codices.unifr. $\mathrm{ch} / \mathrm{de} /$ searchresult/list/one/zbz/Ms-Rh-hist0033b [dostęp: 10 X 2019].

Jacob Leupold, Theatrum Pontificale oder Schau-Platz der Brücken und Brücken-Baues, Leipzig 1726, Max Planck Institute for the History of Science, http://echo.mpiwgberlin.mpg.de/ECHOdocuView? url=/permanent/library/AUFTS19S/index.meta [dostęp: 31 X 2019].

Stanisław Sarnicki, Księgi Hetmańskie z dziejów rycerskich wszystkich wieków zebrane i praktyka abo experientia hetmanów Najjaśniejszego Zygmunta Starego Króla Polskiego, a także Cesarza Karla V i Solimana Tureckiego dwu panów walecznych za naszego wieku objaśnione ku ćwiczeniu mtodych ludzi nacyjej naszej Polskiejpod tytutem, oprac. M. Ferenc, Kraków 2015.

Tratado de la artilleria y uso della platicado por el capitan Diego Ufano en las guerras de Flandes, Brusselas 1613, Biblioteca de la Universidad Complutense de Madrid, http://bibliotecavirtualdefensa.es/BVMDefensa/i18n/consulta/registro.cmd?id= 1192 [dostęp: 31 X 2019].

\section{Opracowania}

Bevan J., Diving bells through the centuries, „South Pacific Underwater Medicine Society Journal" 1999, vol. 29/1, s. 42-50.

Breiding D.H., The Bellifortis of Konrad Kyeser of Eichstätt, [w:] B. Drake Boehm, J. Fajt, Prague. The Crown of Bohemia 1347-1437, New York 2005, s. 233-235.

Drake Boehm B., Fajt J., Wenceslas IV, [w:] B. Drake Boehm, J. Fajt, Prague. The Crown of Bohemia 1347-1437, New York 2005, s. 91-103.

Durdík J., K vojensko-technickým problémuim na poćátku 15. století (Bellifortis Konráda Kyesera), „Historie a vojenství” 1953, z. 3, s. 29-50.

Grabarczyk T., „Sucha stopa” czy „skaczac przez fale”. Przekraczanie rzek przez wojska polskie od XI do poczatku XVI wieku, „Acta Universitatis Lodziensia”, Folia Historica 99, 2017, s. 83-109. 
Kałużyński S., Dawni Mongotowie, Warszawa 1983.

Nowak T., Polska sztuka wojenna w czasach Odrodzenia, Warszawa 1955.

Nowak T., Z dziejów techniki wojskowej w dawnej Polsce, Warszawa 1965.

Rossi C., Russo F., Russo F., Ancient Engineers' Inventions. Precursors of the Present, Heidelberg 2017.

Rutkowska-Płachcińska A., Urzadzenia transportowe i komunikacyjne, [w:] Historia kultury materialnej, t. 2 (od XIII do XV wieku), red. A. Rutkowska-Płachcińska, Wroclaw 1978, s. 204-223.

Sikorski J., Polskie piśmiennictwo wojskowe od XV do XIX wieku, Warszawa 1991.

Strzyż P., Water Obstacles and the Means to Cross Them in Early Medieval Poland, „Fasciculi Archaeologiae Historicae" 2011, fasc. 24, s. 73-78.

Świętosławski W., Breaching of Water Obstacles in the Military Activites of Late Medieval Mongols, „Fasciculi Archaeologiae Historicae” 2011, fasc. 24, s. 79-82.

Piotr Strzyż

\title{
"URINATOR'S CRAFTSMANSHIP AS RIVERS FLOW" OR HOW WATER OBSTACLES WERE BREACHED IN THE $15^{\text {TH }}$ AND $16^{\text {TH }}$ CENTURIES
}

\begin{abstract}
Summary. In the past, people used various methods in order to cross water obstacles: they used fords, built bridges and rafts, or finally resorted to boats of different design. However, military treaties from those times also mention other solutions which could be used in special circumstances. They included special devices which allowed breathing and moving underwater, on the bottom of the reservoir. They were used by Urinatores, the people who could be entrusted with dangerous military sabotage actions against the enemy fleet as well as used for recovering military equipment lost in the water or clearing canals or rivers.

Medieval and Renaissance iconography proves that the instruments occurred in two forms. The first was an inflatable leather belt, buckled on the stomach, with a flexible pipe attached to it. Additional equipment consisted of boots, suitably loaded with lead, and defensive and offensive weapon. The second variant of diving apparatus was a special leather bonnet, fitted with glass-protected eye openings and a long breathing hose with a float sewn to it. Prepared in this way, the diver could spend up to several hours under water. For the territory of the Kingdom of Poland, the relevant information can be found in Księgi Hetmańskie by Stanisław Sarnicki from the second half of the $16^{\text {th }}$ century. Such specialists were certainly useful, but the job undertaken by them was extremely dangerous, particularly if we take into account how primitive the means at their disposal were.
\end{abstract}

Keywords: Kingdom of Poland, urinator, river crossing, War, Middle Ages, $16^{\text {th }}$ century 